\title{
The impact of Schiff bases on antibiotic production by Streptomyces hygroscopicus
}

\author{
Slavica B. Ilić • Sandra S. Konstantinović • \\ Dragiša S. Savić · Vlada B. Veljković • \\ G. Gojgić-Cvijović
}

Received: 3 February 2009/ Accepted: 19 May 2009/Published online: 9 June 2009

(C) The Author(s) 2009. This article is published with open access at Springerlink.com

\begin{abstract}
A media consisting of isatin-Schiff bases (isatin-3-thiosemicarbazone, isatin-3-semicarbazone, and isatin-3-phenylhydrazone) was developed to maximize the production of antibiotics Hexaene H-85 and Azalomycine B by Streptomyces hygroscopicus. The media isatin-3-thiosemicarbazone resulted in the maximum antibiotics concentration of $372 \mu \mathrm{g} \mathrm{cm}^{-3}$ for Hexaene $\mathrm{H}-85$ and $118 \mu \mathrm{g} \mathrm{cm}^{-3}$ for Azalomycine B. The impact of modified media on soil morphology also was investigated.
\end{abstract}

Keywords Streptomyces hygroscopicus - Schiff base - Antibiotic production · Morphology

\section{Introduction}

The genus Actinomyces is an important group of microbes due to their ability to produce commercially valuable secondary metabolites (Abbas and Edwards, 1990; Vučetić et al., 1994; Okami and Hotta, 1988; Prosser and Tough, 1991). The actinomycete Streptomyces hygroscopicus produces a range of polyene antibiotics compounds depending on environmental and nutritional conditions (Vučetić et al., 1994; Karadžić et al., 1991). To make the production of the antibiotic feasible, it is necessary to develop the optimum production, which includes among the other

\footnotetext{
S. B. Ilić $(\bowtie)$ · S. S. Konstantinović · D. S. Savić · V. B. Veljković Faculty of Technology, University of Nis, Bulevar Oslobodjenja 124, Leskovac 16000, Serbia

e-mail: ilicslavica@yahoo.com

S. S. Konstantinović

e-mail: sakisandra12@yahoo.com

G. Gojgić-Cvijović

Department of Chemistry, ICTM, Njegoševa 12, Belgrade 11000, Serbia
} 
conditions, formation of chemically defined media. There have been some investigations about different nitrogen and carbon sources on growth and production (Abbas and Edwards, 1990; Lee et al., 1997; de Queiroz Sousa et al., 2001; Tripathi et al., 2004), but no data are available about the influence of Schiff base. In the present study, an extensive study has been made on the isatin-Schiff bases as a nitrogen source in chemically defined media on antibiotic production by Streptomyces hygroscopicus as well as on soil morphology.

\section{Materials and methods}

Organism, media, and growth condition

A strain Streptomyces hygroscopicus was isolated from a soil sample from Vojvodina, Serbia (Vučetić et al., 1994; Karadžić et al., 1991). Streptomyces hygroscopicus was maintained as spore and mycelia suspensions in sterile glycerol $\left(20 \%\right.$ [wt/vol]), which were prepared from speculated colonies grown at $30^{\circ} \mathrm{C}$ on $\mathrm{L}$ agar that contained the following (in $\mathrm{g}^{-1}$ ): tryptone (Difco Laboratories), 5; yeast extract (Lab-M), 5; NaCl, 5; glucose, 1; agar, 10 (pH 7.2). Suspensions were stored at $-20^{\circ} \mathrm{C}$ until required. Liquid cultures were grown in starch-yeast extract (SY) broth that contained the following (in $\mathrm{g}^{-1}$ ): soluble starch, 15; yeast extract (Difco), $1 ; \mathrm{K}_{2} \mathrm{HPO} 4 \cdot 7 \mathrm{H}_{2} 0,1 ; \mathrm{NaCl}, 3$ (final pH adjusted to 7.2). Flasks (250 ml) that contained $50 \mathrm{ml}$ of this media were inoculated with $0.1 \mathrm{ml}$ of spore suspension and incubated at $30^{\circ} \mathrm{C}$ with shaking at $200 \mathrm{rpm}$. The fermentation media were inoculated with $5 \%(\mathrm{v} / \mathrm{v})$ of a preculture after $48 \mathrm{~h}$ growth and incubated at $30^{\circ} \mathrm{C}$ for $240 \mathrm{~h}$ under the standard condition of aeration and agitation $(200 \mathrm{rpm})$. The fermentation basal media has the following composition (g/l): glucose $15, \mathrm{CaCO}_{3} 3$, $\mathrm{NaCl} 3, \mathrm{MgSO}_{4}$ 0.5, $\left(\mathrm{NH}_{4}\right)_{2} \mathrm{HPO}_{4} 0.5, \mathrm{~K}_{2} \mathrm{HPO}_{4} 0.5$, soya bean 1.0. The fermentation modified media has the follow composition (g/l): glucose $15, \mathrm{CaCO}_{3} 3, \mathrm{NaCl} 3$, $\mathrm{MgSO}_{4}$ 0.5, $\left(\mathrm{NH}_{4}\right)_{2} \mathrm{HPO}_{4} 0.5, \mathrm{~K}_{2} \mathrm{HPO}_{4}$ 0.5, L-tryptophan 0.5, Schiff base 0.5.

After fermentation, the antibiotics of the broth were determined by extraction with $n$-butanol and ethyl acetate. The results were obtained by measuring absorbance at $\lambda_{\max }=364 \mathrm{~nm}$ (Hexaene H-85) and $\lambda_{\max }=252 \mathrm{~nm}$ (Azalomycine) with Perkin-Elmer Lambda 15 UV/VIS spectrophotometer (Vučetić et al., 1994; Karadžić et al., 1991). Growth was determined by measuring dry weights of cells. The broth was centrifuged at $4000 \mathrm{rpm}$ for $15 \mathrm{~min}$ to separate the mycelial biomass. After that biomass was dried at $105^{\circ} \mathrm{C}$ to constant weight and weighed.

\section{General methods of preparation of Schiff bases}

Equimolar amounts of isatin and thiosemicarbazide, semicarbazide, and phenylhydrazine were dissolved in $95 \%$ ethanol. The solutions were heated under reflux for $1 \mathrm{~h}$. The products were filtered, washed with ethanol, and dried in vacuum over $\mathrm{CaCl}_{2}$ (Konstantinović et al., 2007). The structures of Schiff bases are given in Fig. 1. 
Fig. 1 Structures of Schiff bases<smiles>NC(=S)N/N=C1\C(=O)Nc2ccccc21</smiles>

isatin-3-thiosemicarbazone<smiles>NC(=O)N/N=C1\C(=O)Nc2ccccc21</smiles>

isatin-3-semicarbazone<smiles>O=C1Nc2ccccc2/C1=N/Nc1ccccc1</smiles>

isatin-3-phenylhydrazone

\section{Methods}

Microanalysis for carbon, hydrogen, and nitrogen was performed by using a Carlo Erba 1106 microanalyzer. The chloride content was determined potentiometrically. The melting points were determined by using Thomas-Hoover melting point apparatus and are uncorrected. FTIR spectra were recorded using a Michaelson Bomen MB-series spectrophotometer, using $\mathrm{KBr}$ pellet $(1 \mathrm{mg} / 100 \mathrm{mg}$ ) technique. The electronic spectra were recorded on a Perkin/Elmer Lambda 15 UV/VIS spectrophotometer using $10^{-3} \mathrm{~mol} \mathrm{dm}{ }^{-3}$ solutions in DMF. ${ }^{1} \mathrm{H}$ NMR spectra were obtained in DMSO solution with a Gemini-200 "HF NMR" spectrometer.

\section{Isatin-3-thiosemicarbazone (ITC)}

Yield 91.1\%, Color Yellow. m.p. 239-241 ${ }^{\circ} \mathrm{C} . \mathrm{IR}\left(\mathrm{KBr}, \mathrm{cm}^{-1}\right): 3470,3304 v\left(\mathrm{NH}_{2}\right)$, 3239, $3132 v(\mathrm{NH}), 1710 v(\mathrm{C}=\mathrm{O}), 1585 v(\mathrm{C}=\mathrm{N}), 1250 v(\mathrm{C}=\mathrm{S})$. UV/VIS (DMF, $\lambda$ $\left(\mathrm{nm} / \varepsilon \cdot 10^{3}\left(\mathrm{~mol}^{-1} \mathrm{dm}^{3} \mathrm{~cm}\right): 349 / 0.946 \pi \rightarrow \pi^{*}, 366 / 1.325 \pi \rightarrow \pi^{*}{ }^{1} \mathrm{H}\right.$ NMR (DMSO, $\delta$, ppm) 6.9-7.7 (m, 4H, Ar), 8.69, 9.05 (s, 2H, NH $\mathrm{NH}_{2}, 11.21(2,1 \mathrm{H}, \mathrm{NH})$, 12.47 (s, 1H, NH). Analysis: Found: $49.05 \% \mathrm{C}, 3.75 \% \mathrm{H}, 25.30 \% \mathrm{~N}, 14.51 \% \mathrm{~S}$; Calculated: $49.08 \% \mathrm{C}, 3.70 \% \mathrm{H}, 25.32 \% \mathrm{~N}, 14.56 \% \mathrm{~S}$. 
Isatin-3-semicarbazone (ISC)

Yield 90.5\%, Color Yellow. m.p. $239^{\circ} \mathrm{C}$. IR $\left(\mathrm{KBr}, \mathrm{cm}^{-1}\right): 3467,3301 v\left(\mathrm{NH}_{2}\right), 3237$, $3126 v(\mathrm{NH}), 1704,1686 v(\mathrm{C}=\mathrm{O}), 1595 v(\mathrm{C}=\mathrm{N})$. UV/VIS (DMF, $v\left(\mathrm{~cm}^{-1} /\right.$ $\varepsilon \cdot 10^{3}\left(\mathrm{~mol}^{-1} \mathrm{dm}^{3} \mathrm{~cm}\right): 321.8 / 3.121 \pi \rightarrow \pi^{*}, 271.8 / 2.662 \pi \rightarrow \pi^{*} .{ }^{1} \mathrm{H}$ NMR (DMSO, $\delta, \mathrm{ppm})$ 6.02-7.94 (m, 4H, Ar), 8.34, $9.02\left(\mathrm{~s}, 2 \mathrm{H}, \mathrm{NH}_{2}\right), 11.21(2,1 \mathrm{H}$, $\mathrm{NH}), 12.42$ (s, 1H, NH). Analysis: Found: $52.92 \% \mathrm{C}, 3.95 \% \mathrm{H}, 27.45 \% \mathrm{~N}$; Calculated: $52.94 \% \mathrm{C}, 3.92 \% \mathrm{H}, 27.45 \% \mathrm{~N}$.

\section{Isatin-3-phenylhydrazone (IPH)}

Yield 47.89\%, Color orange, m.p. $249^{\circ} \mathrm{C}$. IR $\left(\mathrm{KBr}, \mathrm{cm}^{-1}\right): 3326,3161 v(\mathrm{NH}), 1686$ $v(\mathrm{C}=\mathrm{O}), 1597 v(\mathrm{C}=\mathrm{N})$. UV/VIS (DMF, $v\left(\mathrm{~cm}^{-1} / \varepsilon \cdot 10^{3}\left(\mathrm{~mol}^{-1} \mathrm{dm}^{3} \mathrm{~cm}\right): 398.5 / 2.260\right.$ $\pi \rightarrow \pi^{*}, 258.5 / 1.625 \pi \rightarrow \pi^{*}, 207.5 / 2.914 \pi \rightarrow \pi^{*} .{ }^{1} \mathrm{H}$ NMR (DMSO, $\delta, \mathrm{ppm}$ ) 6.91-7.57 (m, 4H, Ar), 11.00 (2, 1H, NH), 11,00 (s) (2, 1H, NH), 12.32 (s, 1H, NH). Analysis: Found: $70.86 \% \mathrm{C}, 4.62 \% \mathrm{H}, 17.70 \% \mathrm{~N}$; Calculated: $70.89 \% \mathrm{C}, 4.64 \% \mathrm{H}$, $17.72 \% \mathrm{~N}$.

\section{Results and discussion}

Influence of Schiff bases production of Hexaene H-85 and Azalomycine B

To improve production of Hexaene H-85 and Azalomycine B by Streptomyces hygroscopicus, part of soya bean $(0.5 \%)$ in basal medium was replaced with isatin Schiff bases (ITC, ISC, and IPH) as a nitrogen source. The maximum concentration of Hexaene H-85 and Azalomycine B (Fig. 2), pH and dry biomass, achieved during the fermentation in basal and modified media are given in Table 1.

Change of $\mathrm{pH}$ values

Considering all media, as it can be seen, $\mathrm{pH}$ increases until the third or fourth day. The basal medium possesses the highest $\mathrm{pH} 9.3$, whereas the maximum values of $\mathrm{pH}$ in tested media is in the range 8.1-8.4 (Fig. 2a).

Glucose utilization

As shown in Fig. 2b, Schiff bases do not have any impact on glucose utilization during the fermentation. In the control medium, the glucose utilization is finished by the third day, whereas media with Schiff bases possess a small amount of unused glucose.

Dry biomass

As shown in Table 1, the addition of Schiff bases to media slightly increases the growth of production soil. The maximum concentration $\left(9.6 \mathrm{~g} \mathrm{dm}^{-3}\right)$ of dry 

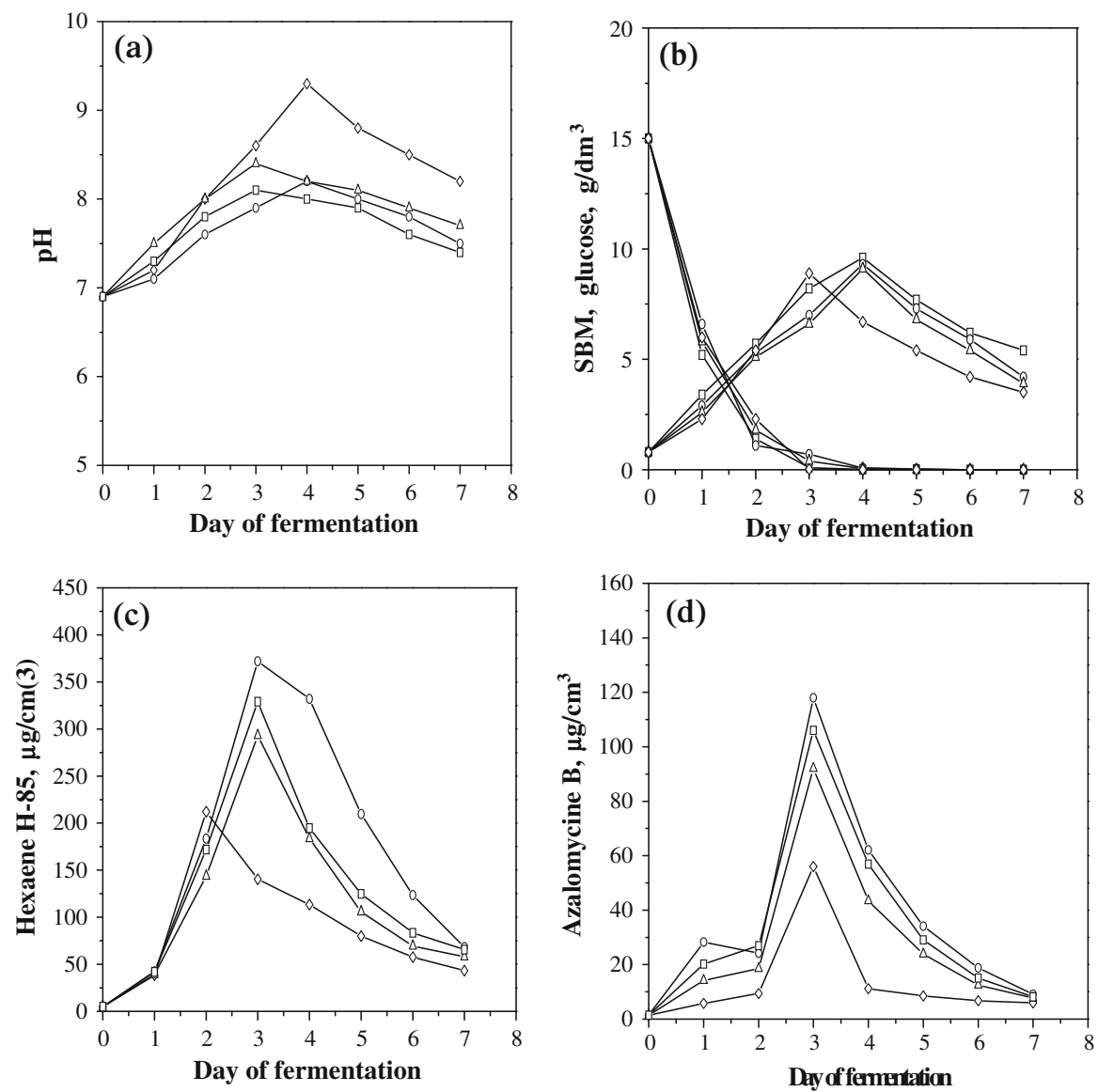

Fig. 2 Change of $\mathrm{pH}(\mathbf{a})$, concentration of glucose and dry biomass (b), concentration of Hexaene H-85 (c), and Azalomycine B (d) in basal medium (- $\left.\diamond_{-}\right)$and media with Schiff bases: ITC (-○-), ISC (- $\left.\Delta-\right)$, and IPH (- $\square$-)

biomass is reached by the fourth day of fermentation in medium with ITC. The values are lower for media with ISC and IPH $\left(9.3 \mathrm{~g} \mathrm{dm}^{-3}\right.$ and $9.1 \mathrm{~g} \mathrm{dm}^{-3}$, respectively). The maximum concentration of dry biomass in basal medium is reached by the third day and its value is $8.9 \mathrm{~g} \mathrm{dm}^{-3}$ ).

\section{Production of Hexaene H-85}

The addition of Schiff bases is stimulated the production of Hexaene H-85, and the values are higher than basal medium. Maximum concentration of antibiotic is reached by the third day in basal medium and by third and fourth days in modified media (Table 1). The maximum concentration of Hexaene H-85 in medium with ITC is $372 \mu \mathrm{g} \mathrm{cm}^{-3}$, which is for $63 \%$ higher compared with basal medium 
Table 1 Impact of Schiff bases on maximum specific rate of glucose utilization $\left(k_{\max }\right)$, maximum concentration of dry biomass $\left(X_{\max }\right)$, and maximum production $\left(C_{\max }\right)$ and yield of antibiotics $\left(Y_{\max }\right)$ during the fermentation of $S$. hygroscopicusa

\begin{tabular}{|c|c|c|c|c|c|c|}
\hline \multirow[t]{2}{*}{ Nitrogen source } & \multirow{2}{*}{$\begin{array}{l}k_{\max } \\
\mathrm{d}^{-1}\end{array}$} & \multirow{2}{*}{$\begin{array}{l}X_{\max } \\
\mathrm{g} \mathrm{dm}^{-3}\end{array}$} & \multicolumn{2}{|c|}{ Hexaene $\mathrm{H}-85$} & \multicolumn{2}{|c|}{ Azalomycine B } \\
\hline & & & $\begin{array}{l}C_{\max }^{\mathrm{H}} \\
\mu \mathrm{g} \mathrm{cm}^{-3}\end{array}$ & $\begin{array}{l}Y_{\max }^{\mathrm{H}} \\
\mu \mathrm{g} \mathrm{g}_{\mathrm{s} . \mathrm{b}}\end{array}$ & $\begin{array}{l}C_{\max }^{\mathrm{A}} \\
\mu \mathrm{g} \mathrm{cm}\end{array}$ & $\begin{array}{l}Y_{\max }^{\mathrm{A}} \\
\mu \mathrm{g} \mathrm{g}_{\mathrm{s} . \mathrm{b}}\end{array}$ \\
\hline SB & 0.97 & 8.9 & 212 & 23.82 & 56 & 6.29 \\
\hline $\mathrm{SB}+\mathrm{ITC}$ & 1.04 & 9.6 & 372 & 38.75 & 118 & 12.29 \\
\hline $\mathrm{SB}+\mathrm{ISC}$ & 1.01 & 9.3 & 293 & 31.50 & 92 & 9.89 \\
\hline $\mathrm{SB}+\mathrm{IPH}$ & 1.03 & 9.1 & 329 & 36.15 & 106 & 11.64 \\
\hline
\end{tabular}

$S B$ soya bean

$\left(212 \mu \mathrm{g} \mathrm{cm}^{-3}\right)$. The media with other ISC and IPH also stimulated the production of this antibiotic for $32 \%$ and $52 \%$, respectively, compared with the basal medium, but the values are lower than medium with ITC $\left(293 \mu \mathrm{g} \mathrm{cm}^{-3}\right.$ and $329 \mu \mathrm{g} \mathrm{cm}^{-3}$, respectively; Fig. 3c).

\section{Production of Azalomycine B}

The addition of Schiff bases also stimulated the production of Azalomycine B (Table 1). The highest concentration is achieved on the fourth day of fermentation. Compared to the basal medium, ITC increases the concentration of antibiotic two times, whereas ISC and IPH increase the production of the same antibiotic by $85 \%$ and $57 \%$, respectively (Fig. 3d).

The mechanism of action of tested Schiff bases was not examined in this work, but there is no doubt that those compounds can be used as a carbon source for antibiotic production. In this study, we used those compounds as a nitrogen source, because there is a similarity between L-tryptophan, an amino acid already used as a nitrogen source in a basal medium, and used Schiff bases. There is a probably a connection between the structure of Schiff bases and their impact on antibiotic production. The ITC has the highest influence on antibiotic production, and yet the only difference compared with ISC is in $\mathrm{C}=\mathrm{S}$ group, which ITC possesses and it is known that biological activity of Schiff bases is due to $\mathrm{C}=\mathrm{N}$ group and $\mathrm{C}=\mathrm{S}$ group if compound contained it.

\section{Impact of Schiff bases on strain morphology}

During fermentation, the nutrient media with isatin Schiff bases, as a nitrogen source, the strain is in the form of pellets, and little of single, free filaments (Table 2). The morphology of S. hygroscopicus is shown in Fig. 3. 
(a)
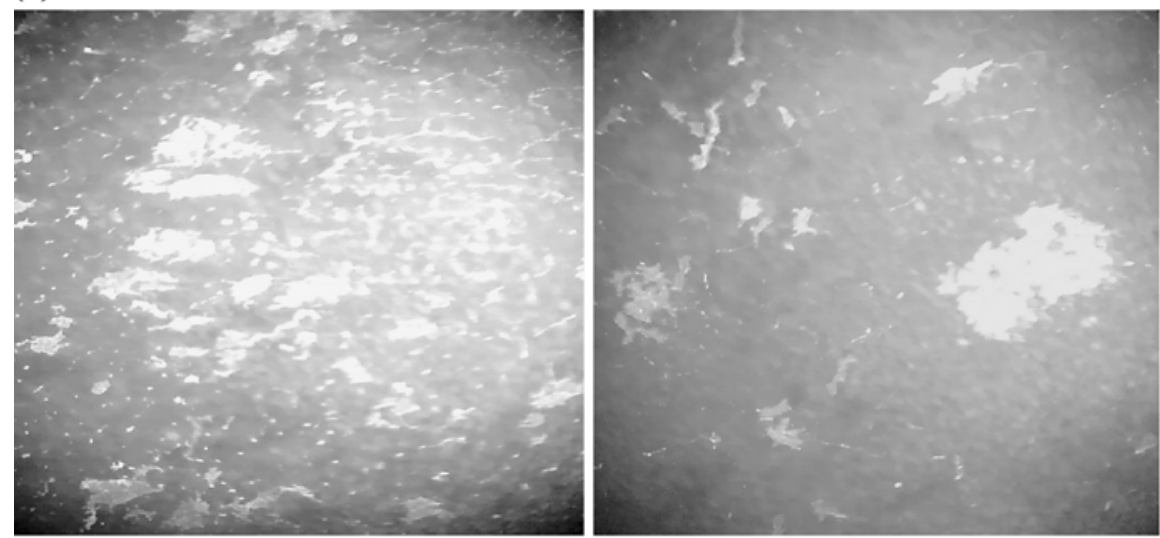

(b)
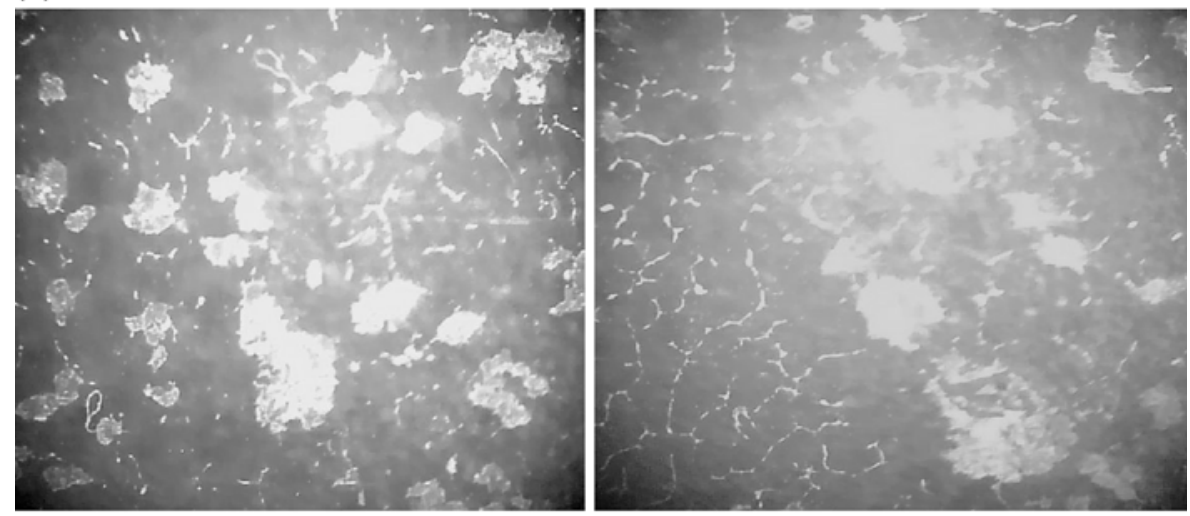

(c)
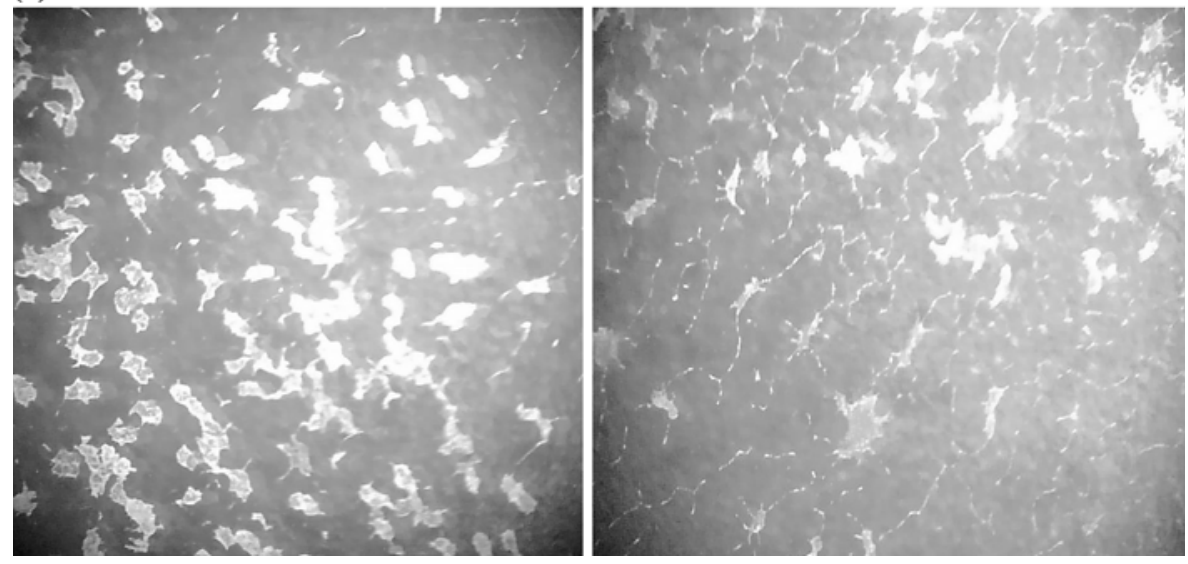

Fig. 3 Morphology of S. hygroscopicus in basal medium and media with Schiff bases: a ITC, b ISC, and c IPH 
Table 2 Impact of Schiff bases on morphology S. hygroscopicus and production of antibiotics

\begin{tabular}{lllr}
\hline Nitrogen source & Strain morphology & Yield of antibiotics \\
& & $Y_{\max }^{\mathrm{H}}$ & $Y_{\max }^{\mathrm{A}}$ \\
\hline ITC & Pellets, single, weakly branched fillaments & 38.75 & 12.29 \\
ISC & Pellets, single, weakly branched fillaments & 31.50 & 9.89 \\
IPH & Pellet, a little of sinlge fillaments & 36.15 & 11.64 \\
\hline
\end{tabular}

Open Access This article is distributed under the terms of the Creative Commons Attribution Noncommercial License which permits any noncommercial use, distribution, and reproduction in any medium, provided the original author(s) and source are credited.

\section{References}

Abbas A, Edwards C (1990) Effects of metals on Streptomyces coelicolor growth and actinorhodin production. Appl Environ Microbiol 56:675-680

de Queiroz Sousa MFV, Lopes CE, Pereira Junior NA (2001) Chemically defined media for production of actinomycin D by Streptomyces parvulus. Braz Arch Biol Technol 44:227-235

Karadžić I, Gojgić-Cvijović G, Vučetić J (1991) Hexaene H-85, a hexaene H-85 macrolide complex. J Antibiot 12:1452-1453

Konstantinović SS, Radovanović BC, Krklješ A (2007) Thermal behaviour of Co(II), Ni(II), Cu(II), $\mathrm{Zn}(\mathrm{II}), \mathrm{Hg}(\mathrm{II})$ and $\mathrm{Pd}(\mathrm{II})$ complexes with isatin- $\beta$-thiosemicarbazone. $\mathrm{J}$ Therm Anal Calorim 90:525-531. doi:10.1007/s10973-006-7794-9

Lee MS, Kojima I, Demain AL (1997) Effect of nitrogen source on biosynthesis of rapamycin by Streptomyces hygroscopicus. J Ind Microbiol Biotechnol 19:83-86. doi:10.1038/sj.jim.2900434

Okami Y, Hotta K (1988) Search and discovery of new antibiotics. In: Goodfellow M, Williams ST, Mordarski M (eds) Actinomycetes in biotechnology. Academic Press, San Diego, CA, pp 33-67

Prosser JI, Tough AJ (1991) Growth mechanisms and growth kinetics of filamentous microorganisms. Crit Rev Biotechnol 10:253-274. doi:10.3109/07388559109038211

Tripathi CKM, Praveen V, Singh V, Bihari V (2004) Production of antibacterial and antifungal metabolites Streptomyces violaceusniger and media optimization studies for the maximum metabolite production. Med Chem Res 13:790-799. doi:10.1007/s00044-004-0118-3

Vučetić J, Karadžić I, Gojgić-Cvijović G, Radovanović E (1994) Improving hexaene H-85 production by Streptomyces hygroscopicus. J Serb Chem Soc 59:973-980 